\title{
Glass Property Models, Constraints, and Formulation Approaches for Vitrification of High-Level Nuclear Wastes at the US Hanford Site
}

\author{
Dongsang Kim ${ }^{\dagger}$ \\ Pacific Northwest National Laboratory, Richland, WA 99352, United States \\ (Received January 29, 2015; Accepted February 11, 2015)
}

\begin{abstract}
Current plans for legacy nuclear wastes stored in underground tanks at the U.S. Department of Energy's Hanford Site in Washington are that they will be separated into high-level waste and low-activity waste fractions that will be vitrified separately. Formulating optimized glass compositions that maximize the waste loading in glass is critical for successful and economical treatment and immobilization of these nuclear wastes. Glass property-composition models have been developed and applied to formulate glass compositions for various objectives for the past several decades. Property models with associated uncertainties combined with composition and property constraints have been used to develop preliminary glass formulation algorithms designed for vitrification process control and waste-form qualification at the planned waste vitrification plant. This paper provides an overview of the current status of glass property-composition models, constraints applicable to Hanford waste vitrification, and glass formulation approaches that have been developed for vitrification of hazardous and highly radioactive wastes stored at the Hanford Site.
\end{abstract}

Key words : Nuclear waste, High-level waste, Glass formulation, Vitrification, Property model

\section{Introduction}

$\mathrm{T}$ he U.S. Department of Energy (DOE) is responsible for treating, vitrifying, and disposing of a large volume of legacy nuclear wastes that are byproducts of plutonium production during the Cold War era. These wastes are stored in underground tanks at the Savannah River Site (SRS) in South Carolina and at the Hanford Site in Washington State. Joule-heated, slurry-fed ceramic melters are in use at SRS and will be used at Hanford to produce borosilicate glass waste forms. ${ }^{1-2)}$ Over 16 million liters of waste have been treated and vitrified, producing more than 6,800 metric tons of glass at the Defense Waste Processing Facility (DWPF) at SRS since its startup in 1996. The tank waste at Hanford Site are planned to be separated into a low-volume, high-level waste (HLW) fraction and a high-volume lowactivity waste (LAW) fraction through pretreatment processes. $^{3-6)}$ Each waste stream will be vitrified separately at the Hanford Tank Waste Treatment and Immobilization Plant (WTP), which currently is under construction (Fig. 1), and the molten glass then will be poured into large stainless steel canisters (HLW) and containers (LAW) (Fig. 2). ${ }^{3-6)}$ The immobilized LAW containers will be disposed of onsite in trenches covered with soil, and the immobilized HLW glass canisters will be shipped to a yet-be-determined federal geo-

Corresponding author : Dongsang Kim

E-mail : dongsang.kim@pnnl.gov

Tel : +1-509-372-4611 Fax : +1-509-372-5997 logic repository for permanent disposal deep underground. ${ }^{4)}$ A nuclear waste glass must meet a number of composition and property constraints. ${ }^{6}$ There are two categories of constraints: 1) acceptance or performance of the waste form product and 2) processability of waste glass feed ${ }^{\mathrm{a}}$ for a given melting technology. Much data on the properties of glass and glass melt and the melting characteristics of waste glass feeds have been generated during the past several decades. Various glass formulation approaches have been developed to design glass compositions that satisfy all the composition and property requirements for a given waste or set of wastes. This article introduces the glass property models, composition and glass property constraints, and glass formulation approaches that have been developed for vitrification of hazardous and radioactive wastes stored at Hanford. This short contribution is intended to present an overview of methods and concepts that have been developed and adopted for Hanford waste glass formulations, but not to provide comprehensive details on the data associated with the extensive array glasses with varying compositions that have been formulated for the Hanford.

\footnotetext{
a) The term "feed" is used in the waste vitrification community to describe the slurry mix of waste (liquid or slurry) and additive materials such as silica sand, $\mathrm{Na}_{2} \mathrm{CO}_{3}$, boric acid, etc. The slurry "melter feed," also referred to as "waste glass feed," is fed to a "glass melter," which is equivalent to a glass furnace in the commercial glass industry.
} 


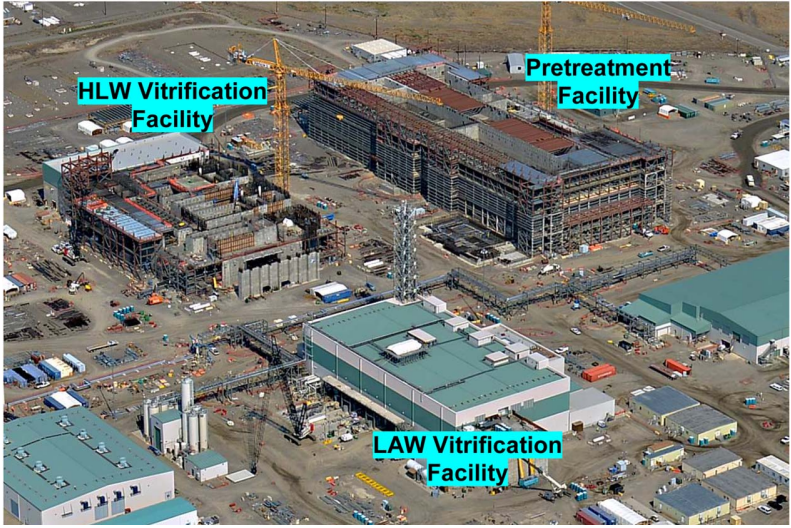

Fig. 1. Aerial photograph of the WTP under construction at DOE's Hanford Site in Washington State (as of July 2014, Source: www.hanfordvitplant.com).

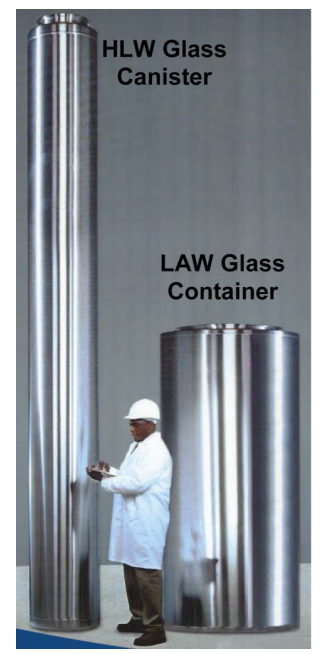

Fig. 2. Stainless steel containers and canisters for LAW and HLW glasses to be produced at the WTP (www.hanfordvitplant.com).

\section{Waste Glass Formulation}

In a broader term, glass formulation can be defined as designing a glass composition for a specific application. In this regard, glass formulation does not include formulating feed recipes (of raw materials) for a given glass composition. For commercial applications, the objective can be designing a new glass composition for a new product or modifying the existing composition for product improvement or process changes. Glass formulation is needed in various stages of waste vitrification technology development; for example, formulating a glass for a specific waste to demonstrate a new processing technology, ${ }^{7-10)}$ developing enhanced glass formulations for specific Hanford wastes, ${ }^{11-15)}$ or formulating a glass frit composition for each sludge batch to produce actual radioactive glass at the DWPF. ${ }^{16,17)}$ The last case also involves variability confirmation so that the selected composition can tolerate the uncertainties from various sources. ${ }^{18,19)}$

In a narrower interpretation of the term, waste glass for- mulation cab be described as finding an additive composition that maximizes the waste throughput rate while meeting all the processing and quality constraints. Waste throughput rate is a term used to describe the rate of waste converted to glass by vitrification, which is defined as follows:

\section{[waste throughput rate] $=$ \\ [waste loading in glass] $\times$ [glass melting rate]}

Currently, the maximum waste loading can be estimated based on the glass property models, which is the main subject of subsequent sections in this article. However, although considerable efforts have been made to understand the factors that control the melting rate and to develop simple correlations or tools that can be used to estimate the melting rate, ${ }^{20-31)}$ models for predicting glass melting rate from glass or feed composition are not available. Extensive studies have been and are currently being performed to investigate the fundamentals of feed melting reactions during the early stages of the cold-cap melting process ${ }^{32-41)}$ and to eventually develop mathematical models ${ }^{42-46)}$ that can be used to predict the melting rate based on feed chemistry.

Waste glass formulation uses a simple mass balance:

$$
\begin{aligned}
& g_{i}=W w_{i}+(1-W) a_{i} \\
& \sum_{i=1}^{n} g_{i}=1, \sum_{i=1}^{n} w_{i}=1, \sum_{i=1}^{n} a_{i}=1
\end{aligned}
$$

where $g_{i}, w_{i}$, and $a_{i}$ are the mass fractions of $i^{\text {th }}$ component in glass, waste, and additives, respectively; $W$ is the waste loading; and $n$ is the number of components in the glass. The composition of waste, glass, and additives are expressed in terms of oxides (e.g., $\mathrm{B}_{2} \mathrm{O}_{3}, \mathrm{SiO}_{2}, \mathrm{Na}_{2} \mathrm{O}$, and $\mathrm{SO}_{3}$ ) and halogens (e.g., $\mathrm{F}$ and $\mathrm{Cl}$ ) for non-volatile and semivolatile components. Carbonates, nitrates, organic carbons, etc., that completely volatilize during processing are not included. For convenience, the term "oxides" includes halogens, for example, the waste oxide loading (or simply, the waste loading) is the mass fraction of oxides and halogens contributed by the waste to the glass. The waste glass formulation usually means finding the additive composition $\left(a_{i}\right)$ to yield a glass composition $\left(g_{i}\right)$ that satisfies constraints while maximizing the loading $(W)$ of a given waste $\left(w_{i}\right)$.

\section{Glass Property Models}

Property-composition models are applied to all types of glass formulation efforts. There are two categories of glass property models: 1) empirical models and 2) mechanistic models. Empirical models determine the model coefficients from measured properties of glasses with varied compositions. Mechanistic models derive the model form and the relationships between model coefficients from fundamental principles of physics and chemistry or glass structure, however, all mod- 
els fit some parameters to experimental data. ${ }^{47-53)}$ First-principle models, i.e., those based on fundamental physical principles and not fit to experimental data, are not currently applicable to predicting waste glass properties. Empirical models are used exclusively for glass formulation efforts for Hanford wastes because mechanistic models do not fit the measured data for the multicomponent waste glasses well enough to be applied to plant process and product controls with sufficient confidence. ${ }^{54-70)}$

A simple first-order model form without temperature term is expressed as:

$$
P=\sum_{i=1}^{n} p_{i} x_{i}
$$

where $P$ is the property, $p_{i}$ is the $i^{\text {th }}$ component coefficient, and $x_{i}$ is the $i^{\text {th }}$ component normalized mass or mole fraction in glass $\left(\sum_{i=1}^{n} x_{i}=1\right)$. Note than $P$ also can be the transformation of property (e.g., $\ln (\eta)$ for the natural logarithm of viscosity $[\eta])$. Eq. (3) is referred to as a linear mixture (LM) model.

For the compositions of the glasses with relatively narrow ranges of concentrations, most non-linear effects of individual components may be approximated by the first-order model given in Eq. (3). However, as glass compositions expand to wider concentration ranges, the first-order model form may not be adequate for certain properties and components with strong non-linear effects, as illustrated in Fig. $3{ }^{71)}$ Adding non-linear terms may be helpful for those components. The secondorder model form that includes squared and cross-product terms is given as:

$$
P=\sum_{i=1}^{n} p_{i} x_{i}+\text { Selected }\left\{\sum_{i=1}^{n} p_{i i} x_{i}^{2}+\sum_{i<j}^{n-1} \sum_{i j}^{n} p_{i j} x_{i} x_{j}\right\}
$$

where $p_{i i}$ is the coefficient for the $i^{\text {th }}$ component squared and $p_{i j}$ is the coefficient for the cross-product of the $i^{\text {th }}$ and $j^{\text {th }}$

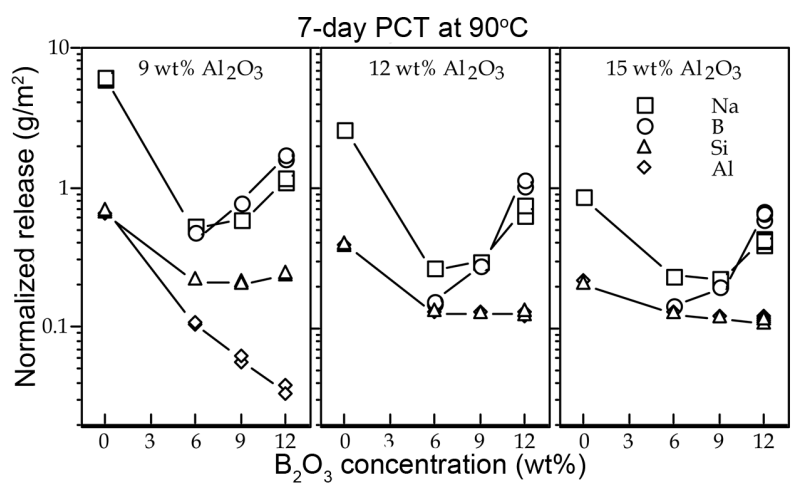

Fig. 3. Normalized elemental releases after 7-Day PCT at $90^{\circ} \mathrm{C}$ as a function of $\mathrm{B}_{2} \mathrm{O}_{3}$ concentration in simple glasses with different levels of $\mathrm{Al}_{2} \mathrm{O}_{3}$. All glasses had $20 \mathrm{wt} \% \mathrm{Na}_{2} \mathrm{O}$ and $2.2 \mathrm{wt} \%$ total minor waste components. The balance was $\mathrm{SiO}_{2}$, which was replaced by $\mathrm{B}_{2} \mathrm{O}_{3}$ at each $\mathrm{Al}_{2} \mathrm{O}_{3}$ concentration. ${ }^{71}$ components. The term "Selected" is used to specify that the $p_{i i}$ and $p_{i j}$ are obtained from experimental data for selected components and cross-products only. Eq. (4) also is referred to as a partial quadratic mixture (PQM) model.

For properties that depend on temperature, viscosity and electrical conductivity, several methods have been employed. For the most typical approach used for viscosity and electrical conductivity $(\varepsilon)$, temperature dependence is often fitted by the Arrhenius equation:

$$
\ln (\eta) \text { or } \ln (\varepsilon)=A+\frac{B}{T}
$$

where $A$ and $B$ are the temperature-independent constants and $T$ is the temperature (in $\mathrm{K}$ ). Then, the constants $A$ and $B$ can be expressed as a function of composition based on the LM or PQM introduced above. Using the LM as an example, Eq. (5) yields:

$$
\ln (\eta) \text { or } \ln (\varepsilon)=\sum_{i=1}^{n} A_{i} x_{i}+\frac{\sum_{i=1}^{n} B_{i} x_{i}}{T}
$$

where $A_{i}$ and $B_{i}$ are the $i^{\text {th }}$ component coefficients for the constants $A$ and $B$. In general, the Arrhenius equation works well for electrical conductivity for a wide temperature range; however, for viscosity, it is good only for relatively narrow temperature ranges. For viscosity over a wider temperature range, the Vogel-Fulcher-Tammann (VFT) equation provides a better data fit:

$$
\ln (\eta)=E+\frac{F}{T-T_{0}}
$$

where $E, F$, and $T_{0}$ are the temperature-independent constants. Note that degrees centigrade rather than degrees Kelvin usually are used for $T_{0}$ and $T$ in the VFT equation. Using the LM as an example, Eq. (7) yields:

$$
\ln (\eta)=\sum_{i=1}^{n} E_{i} x_{i}+\frac{\sum_{i=1}^{n} F_{i} x_{i}}{T-\sum_{i=1}^{n} T_{0, i} x_{i}}
$$

where $E_{i}, F_{i}$, and $T_{0, i}$ are the $i^{\text {th }}$ component coefficients for the constants $E, F$, and $T_{0}$. The PQM also can be applied to Arrhenius or VFT equation similarly to Eqs. (6) and (7).

For the temperature range of interest for waste vitrification using a Joule-heated melter operating at a nominal temperature of $1150^{\circ} \mathrm{C}$, the Arrhenius equation works reasonably well for viscosity (i.e., there is no need to use the VFT equation). Furthermore, Ojovan ${ }^{72)}$ and Hrma et al. ${ }^{73-77)}$ argued that the viscosity can be successfully modeled by assuming that the constant $A$ in Eq. is composition-independent. The fewer variables needed to fit the data have an advantage in that the models have smaller prediction uncertainties. This approach has not been applied to WTP models for plant operations, but it needs to be evaluated. 
Modeling the temperature for a fixed viscosity is common in the commercial glass-melting community ${ }^{78,79}$ although it has not been used for waste glasses. Modeling the viscosity or electrical conductivity at a fixed temperature has been used for simple applications such as at $1150^{\circ} \mathrm{C}$ for a Jouleheated melter. ${ }^{54,56,69)}$ Another approach is modeling the measured or estimated (interpolated) $\ln (\eta)$ or $\ln (\varepsilon)$ as a function of composition at multiple fixed temperatures by LM or PQM. Then, the Arrhenius equation, Eq. (7), or the VFT equation, Eq. (7), is used to calculate the viscosity at different temperatures. The VFT, Eq. (7), equation was used by Vienna et al. 2009. ${ }^{69)}$ in models for viscosity and electrical conductivity.

The first step of developing the empirical glass property models is defining the composition and temperature region of interest based on waste composition variations, estimated range of waste loadings, and desired additive components. Any existing property data for the glasses within the composition and temperature region of interest are collected and evaluated. Then, the test matrix that can fill the gap between the existing data and the composition and temperature region of interest is developed. Statistical experimental design methods are used to minimize the number of glasses that need to be tested. ${ }^{54,80-85)}$ Sometimes multiple steps of test matrix design and testing are performed to fully cover the composition and temperature regions of interest. $^{66,67)}$

Model fittings are performed to find the coefficients of model components and temperature parameters that minimize the prediction uncertainties. Selection of model parameters generally is based on a combination of statistically determined outputs and known information on the effect of glass composition and temperature on each glass property. As mentioned earlier, first-principle models are not suited for the multicomponent waste glasses, but mechanistic understanding is sometimes useful in selecting the model parameters. ${ }^{50,52)}$ A separate validation data set or subset of the modeling data is used to independently validate the models and demonstrate the prediction uncertainties. ${ }^{66,67)}$

\section{Constraints for Glass Formulation}

Various constraints are used to ensure that the nuclear waste glass meets diverse criteria or requirements in processability and product quality. The constraints can be in terms of property values or component concentration ranges. Different sets of constraints are developed and applied depending on the objective of each glass formulation effort. This section briefly summarizes the major constraints focused on those currently applicable to the WTP. ${ }^{86,87)}$ Comparisons of different constraints that have been applied for various Hanford applications have been published by Vienna et al. 2013. ${ }^{70)}$ Glass property models are valid only over the composition region where experimental data were available to develop them. Thus, the socalled model validity constraints are imposed, which are given in terms of either component concentrations or property values. $^{86,87)}$

Some constraints are absolute criteria that must be met to satisfy environmental regulations, generally related to the performance of glass product measured under certain test conditions and to the safety of the waste treatment and disposal facilities generally expressed in terms of the activities of selected radionuclides. ${ }^{6)}$ Currently, there are three test methods for glass performance applicable to the WTP: 1) the product consistency test (PCT), ${ }^{88)} 2$ ) the toxicity characteristic leach procedure (TCLP), ${ }^{89}$ and 3) the vapor hydration test (VHT) ${ }^{90)}$ The PCT and TCLP methods are applicable to the HLW glass, and the PCT and VHT methods are applicable to the LAW glass. Table 1 summarizes the PCT, VHT, and TCLP constraints applicable to the WTP.

Constraints for viscosity and electrical conductivity of a glass melt are applied for ease of processing for the given vitrification technology, which is a ceramic-lined Jouleheated melter with Inconel ${ }^{\circledR}$ electrodes and bubblers for the WTP. The lower limit of viscosity is implemented to avoid excessive corrosion of melter components including ceramic melter refractories and metal electrodes and bubblers that are in contact with the molten glass, and to limit potential melt penetration through the refractory lining. ${ }^{54)}$ The upper limit of viscosity is employed to avoid a potential problem with slow melting rate because the melt viscosity is a critical factor that determines the melting rate. ${ }^{24,91)}$ For the WTP, the lower and upper limits at $1150^{\circ} \mathrm{C}$ are 2 and $8 \mathrm{~Pa}$, respectively, for both HLW and LAW glass melts. The constraint for electrical conductivity of molten glass is applied to ensure that glass melting is performed within the design capacity of vitrification facility's power equipment. The lower limit of $10 \mathrm{~S} / \mathrm{m}$ at $1100^{\circ} \mathrm{C}$ and the upper limit of $70 \mathrm{~S} /$ $\mathrm{m}$ at $1200^{\circ} \mathrm{C}$ are used for both HLW and LAW glasses at the WTP. This requirement for electrical conductivity is usually met when the viscosity requirement is met for typical borosilicate glass compositions expected to be produced at Hanford and therefore often not employed for certain glass formulation purposes. ${ }^{62,69)}$

Crystallization may occur in the glass melt and in the

Table 1. PCT, VHT, and TCLP Constraints Applicable to the WTP at DOE's Hanford Site. ${ }^{86,87)}$

\begin{tabular}{ccc}
\hline Constraint & HLW glass & LAW glass \\
& PCT-B $<16.70 \mathrm{~g} / \mathrm{L}$ & PCT-B $<4 \mathrm{~g} / \mathrm{L}$ \\
PCT normalized releases & PCT-Li $<9.57 \mathrm{~g} / \mathrm{L} / \mathrm{PCT}-\mathrm{Na}<4 \mathrm{~g} / \mathrm{L}$ \\
& PCT-Na $<13.35 \mathrm{~g} / \mathrm{L}$ & $<\mathrm{PC}-\mathrm{Si}<4 \mathrm{~g} / \mathrm{L}$ \\
\hline VHT alteration rate at $200^{\circ} \mathrm{C}$ & Not applicable & $<0 \mathrm{~g} / \mathrm{m}^{2} / \mathrm{d}$ \\
\hline TCLP Cd concentration & Cd concentration $<0.48 \mathrm{mg} / \mathrm{L}$ & Not applicable \\
\hline
\end{tabular}


final glass product although the intended waste form would ideally be a homogeneous glass. Crystalline or secondary phases are allowable as long as they do not degrade the glass quality or melt processability and, in turn, lead to a failure to meet the constraints or reduce melter life. Note that constraints related to the crystallization discussed here are applicable only to HLW glasses.

Crystals that form in the melter or pour spout can interfere with melter operation if they settle to the bottom. This is especially true for highly dense crystals such as spinel, zircon, or zirconia. ${ }^{92-96)}$ A glass melt at a temperature below its liquidus temperature $\left(T_{L}\right.$, the highest temperature at which a crystalline phase can exist in the melt at equilibrium) can precipitate crystalline phase in the melter. Historically, $T_{L}$ was constrained to be $100^{\circ} \mathrm{C}$ below the nominal melter processing temperature (i.e., $1050^{\circ} \mathrm{C}$ for the WTP meter operating at $1150^{\circ} \mathrm{C}$ ). However, the equilibrium $T_{L}$ is not a good criterion because it does not provide information on the amount and size of crystals, which are more important for crystal settling. The WTP adopted a constraint to limit the equilibrium volume percent of spinel crystal at $950^{\circ} \mathrm{C}$ to $<1 \%$ (i.e., $T_{1 \%} \leq 950^{\circ} \mathrm{C}$ ). Although this approach considers the importance of crystal volume, it does not allow for the effect of crystal size. Recently, there have been suggestions that the melter may tolerate more than $1 \%$ of crystals at $950^{\circ} \mathrm{C}^{70)}$ Therefore, for mission planning purposes, models that can predict the crystal volume fraction as a function of glass composition and temperature have been developed for use in investigating the effect of glass crystal tolerance on the volume of Hanford waste glass to be produced. $^{70)}$ Meanwhile, extensive studies are being performed to model the effect of glass composition on the settling rate so that more realistic glass formulations that are not overly conservative can be possible. ${ }^{97}$ For zirconium-containing crystalline phases, the current WTP constraints apply a set of non-spinel phase rules instead of the property models because of lack of data. ${ }^{87)}$

A homogeneous glass melt can form crystalline phases during cooling of the glass poured in canister. The type and amount of crystals are strongly dependent on the temperature history of the glass. Crystallization of the slowly cooled glass near the center of the canister, simulated by the canister centerline cooling treatment, is intended to represent the highest degree of crystallinity possible within the canister. Formation of certain crystals can result in a severe deterioration of glass chemical durability determined by PCT, especially if nepheline (ideally $\mathrm{NaAlSiO}_{4}$ ) is formed (see Fig. 4). ${ }^{98,99)}$ It is known that the formation of spinel crystals in many HLW glasses does not affect the PCT durability. $^{98,100)}$ To formulate glasses that would not precipitate nepheline, an empirical rule based on a nepheline discriminator $\left(N_{S i}\right)$ was developed ${ }^{101)}$ :

$$
N_{S i}=\frac{g_{S_{i O}}}{g_{\mathrm{SiO}_{2}}+g_{\mathrm{Na}_{2} \mathrm{O}+g_{\mathrm{Al}_{2} \mathrm{O}_{3}}}} \geq 0.62
$$

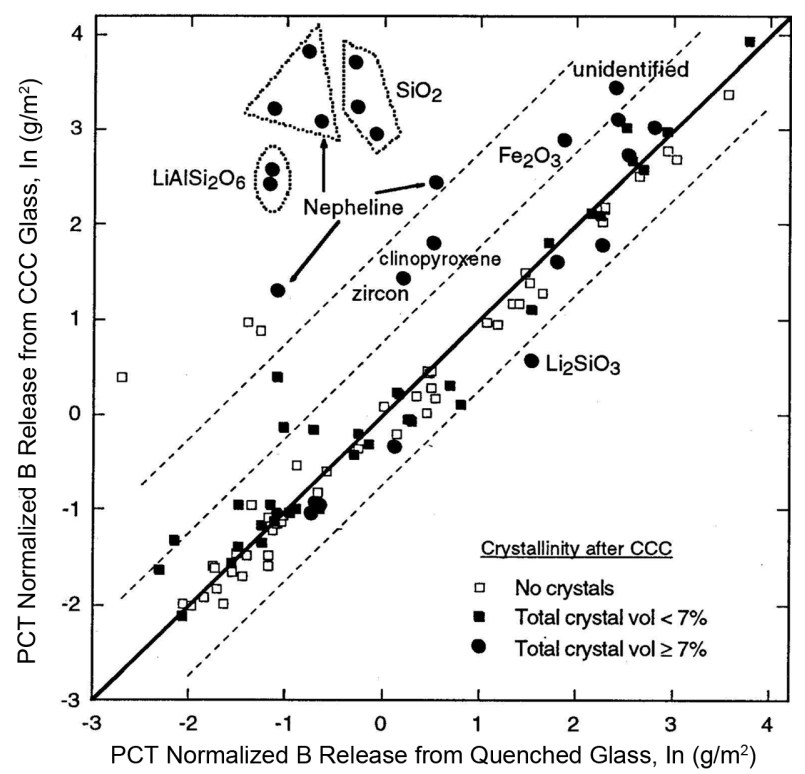

Fig. 4. Normalized boron releases from quenched and simulated canister centerline cooled glasses determined by 7 -Day PCT at $90^{\circ} \mathrm{C} .{ }^{98}$

This nepheline discriminator as a nepheline rule is currently adopted for WTP operation. However, this $N_{S i}$ is very conservative; that is, many glasses that do not form nepheline are excluded from the glass formulation because they fail to satisfy this rule. To alleviate the conservatism, an additional rule based on optical basicity has been developed $^{102,103)}$ :

\section{OB (Optical Basicity) $\leq 0.575$}

The addition of the optical basicity rule help to decrease the conservatism; however, many glasses that do not precipitate nepheline are predicted to form precipitates so the model is still too conservative. Currently, new modeling approaches and basic research focused on understanding the thermodynamic and kinetic aspects of nepheline crystallization are being performed.

Glass melts with excess concentrations of some troublesome anions tend to form an accumulated salt layer on the melt surface. ${ }^{104-107)}$ The salt layer can significantly accelerate corrosion of melter components that, if persistent for long time periods, may cause premature melter failure. In addition, if the melt is supersaturated with salt, water-soluble salts containing key radionuclides may separate during canister cooling. ${ }^{108)}$ The primary component in the salt is sodium sulfate generally mixed with other alkali or alkaline earth anions such as chromate, phosphate, chloride, fluoride, etc. To avoid the deleterious effects of salt, WTP has adopted a single component constraint of $0.44 \mathrm{wt} \% \mathrm{SO}_{3}$ concentration for the HLW glass formulation. ${ }^{87)}$ For LAW, the feed composition is controlled by applying the glass formulation rules, primarily influenced by $\mathrm{SO}_{3}$ concentration, with additional constraints based on chromate and halide con- 
centrations. ${ }^{86)}$ Recently Vienna et al. 2014 ${ }^{108)}$ found that there is a good correlation between the equilibrium sulfate solubility and the sulfate concentration that can be in the melter feed without forming the salt. They proposed applying the $\mathrm{SO}_{3}$ solubility model as a salt-formation constraint for the glass formulation. The $\mathrm{SO}_{3}$ solubility can be measured easily compared to melter data on salt formation. Currently data on the $\mathrm{SO}_{3}$ solubility versus glass composition is being developed so the $\mathrm{SO}_{3}$ solubility can be modeled as a function of glass composition.

It also is known that a scum layer is formed on the surface of the melt for HLW feeds containing high concentrations of phosphorus and calcium or rare earths. ${ }^{109)}$ The scum layer has the potential to cause processing problems similar to those from salt formation. Based on limited data the following preliminary constraints were established for the $\mathrm{WTP}^{87}$ :

$$
\begin{aligned}
& g_{P_{2} O_{5}}<0.045 \\
& g_{P_{2} O_{5}} g_{C a O}<0.00065 \\
& g_{L_{2} O}<0.06
\end{aligned}
$$

The formation of scum (presumably calcium phosphate) is expected to be affected by the concentration of the components that are present in the scum phase, but it also will be affected by the overall composition of glass (i.e., concentrations of other components). Therefore, the limits primarily based on the concentrations of major scum components in Eq. would have a tendency to be conservative because of lack of data on the effects of glass composition. Additional crucible melting and melter tests are being performed to understand the mechanism of scum formation and to develop more practical constraints.

\section{Iterative Glass Formulation}

The iterative glass formulation approach, often referred to as "active" glass design, is used in general for a specific waste when exploring the glass compositions outside the valid composition range of existing models or when models for key properties are not available. ${ }^{7-10,110)}$

Some models perform relatively well when the target glass composition is outside the model validity range. However, it is not possible to estimate the uncertainties for the predicted results when extrapolated to the outside the model validity range. A useful method of effectively using the models for active glass design is to calculate and apply the difference between model predictions for two different glasses when at least one data point is available. For Glass 2 with unknown property values and Glass 1 with known property values:

$$
\mathrm{P}_{2, \text { est }}=\mathrm{P}_{1, \text { meas }}+\mathrm{P}_{2, \text { pred }}-\mathrm{P}_{1, \text { pred }}
$$

where $P_{2, \text { est }}$ is the estimated property value for Glass 2, $P_{1, \text { meas }}$ is the measure property value for Glass 1 , and $P_{1, \text { pred }}$ and $P_{2, \text { pred }}$ are the as-predicted property values by the model for Glasses 1 and 2, respectively. If the model uses the transformed property such as $\ln (\eta)$, that should be used as $P$ in Eq. (12).

The iterative approach focuses on key properties or constraints that are critical in determining the acceptance or processability of the final glass to the initial design set of glass compositions. Then, a next set of glasses are formulated based on the results of the previous set. This iterative process is repeated until a satisfactory composition is achieved. The following detailed steps would be involved:

- Select waste composition: Glass formulations usually are performed on a waste or a set of wastes already specified, but sometimes, it is necessary to select the composition best suited for a specific purpose, such as for demonstration of a new melter technology to increase glass production rate.

- Compile existing glass property data and models: The information learned from existing data and property models are directly used when formulating the initial set of glasses. It is necessary to check the valid composition ranges of the models being used to gain general idea on the uncertainty of the model results. When property data are available near the desired composition region, Eq, (12) is useful.

- Define all constraints and identify key constraints. Evaluating existing data helps to identify the key properties that are likely to limit the waste loading. To facilitate the formulation process and also to provide room for various uncertainties, self-imposed constraints that are different from the regulatory limits can be applied. The key properties may change during the course of glass formulation efforts.

- Formulate and test initial set of glasses: All available property models are used, although extrapolated, to formulate preliminary optimized compositions described in the next section. It is important to use the information gained from evaluating existing glasses and applying available property models to estimate the waste loading limit and formulate the glasses around that loading. Glasses in the next set are formulated based on an evaluation of the results from existing and previous sets of glasses.

- Formulate and test the next set of glasses and repeat the process until a satisfactory composition is obtained: When selecting the final composition it is necessary to account for various uncertainties that originate from model prediction uncertainties or errors related to achieving the exact composition. Sometimes it may be necessary to allow for potential differences between certain properties observed in laboratory crucible tests and those produced in the continuous melter process (e.g., differences in thermal history).

- Characterize all relevant properties: After finding the composition that satisfies the key constraints, it also is necessary to confirm that the final glass will meet other constraints that are not likely to limit the waste loading, but need to be verified.

Examples of glass composition development for selected Hanford HLW and LAW wastes employing the iterative glass formulation steps described above can be found in Kim et al. 2011. ${ }^{110)}$ 


\section{Glass Composition Optimization}

Glass composition optimization is used for various purposes including iterative glass formulation for a specific waste discussed in a previous section, ${ }^{7-10,110)}$ estimation of glass mass to be produced from a set of projected waste compositions, ${ }^{2,4,5,111,112)}$ and glass formulation algorithms to be used for process and product control at WTP. ${ }^{86,87)}$ Glass composition optimization refers to a process of finding the waste loading and additive composition best suited for a given glass formulation objective while satisfying all applicable constraints. Generally, the glass formulation goal is to maximize the waste loading or maximum waste throughput rate to achieve the most cost-effective waste treatment and immobilization. However, sometimes a "robust" glass composition may be desired; that is, a composition designed to minimize the probability of failing the constraints even when unexpected process deviations occur (e.g., the composition with properties that diverge farthest from all the key constraints). Current plans call for the "robust" glass formulation approach to be applied at startup and during initial operation of the WTP ${ }^{87)}$ Over time the glass formulation goal can be revised to gradually move to maximizing the waste loading or waste throughput rate.

Simple glass composition optimization can be accomplished using the commercial spreadsheet tool (Microsoft Excel's "Solver") for simple sensitivity studies ${ }^{111}$ or for demonstration of preliminary algorithms for the WTP ${ }^{86,87)}$ when only limited number of optimization calculations are needed. When many calculations need to be performed for hundreds or thousands of different waste batches for each set of system plan scenarios, dedicated programing is used based on an optimization routine such as the Simplex method. ${ }^{4,5,112)}$

The tank wastes at Hanford are very diverse in composition so it is impossible to formulate the glasses in a batch approach similar to that used at the DWPF, where each batch of waste is ready and glass formulation and demonstration are performed in advance before the waste is processed in the melter. Fig. 5 illustrates how the HLW composition changes with time for a specific tank retrieval and pretreatment scenario. ${ }^{110)}$ The waste composition estimation also evolves as new information (e.g., new waste sample analyses) becomes available, the sequence of tank retrieval is changed, or the pretreatment process is modified. Therefore, it is necessary to develop the glass formulation algorithms that can used to formulate the glasses for any wastes expected during plant operation as soon as each batch of waste from pretreatment is moved to the waste storage vessel in the vitrification facility and analyzed. ${ }^{86,87)}$ The glass formulation algorithms cover the entire process of evaluating the waste composition data, formulating the glass composition using glass property models and sets of constraints after accounting for various uncertainties, calculating the volume of waste to transfer from waste storage vessel to melter feed preparation vessel, calculating the

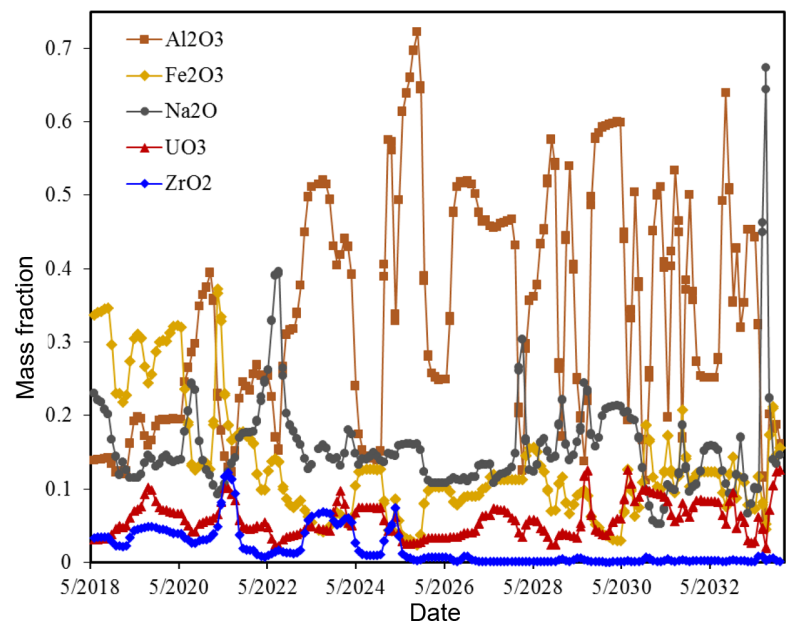

Fig. 5. Example of projected compositions of Hanford HLW batches for selected major Oxide components. ${ }^{110)}$

masses of additives to add, and generating production records based on the analyses of wastes or melter feeds.

\section{Conclusion}

Current preliminary glass formulation algorithms for WTP are based on glass property models developed for a relatively small fraction of wastes from a few tanks and for the glass compositions with conservative waste loading for "robust" glass formulation. A multi-year joint research program of laboratory-scale tests and pilot melter runs is being conducted at Pacific Northwest National Laboratory, the Catholic University of America, the Savannah River National Laboratory (SRNL), and DOE's Office of River Protection. The objectives of this program are twofold: 1) to expand the glass composition regions for full range of tank waste compositions expected at Hanford through development of the glass property data and models and 2) to increase the waste throughput rate by a combination of increased waste loading through advanced glass formulations and enhanced melting rate through understanding feed melting chemistry and modeling cold-cap melting processes.

\section{Acknowledgments}

This work was supported by the US Department of Energy, Office of River Protection, Waste Treatment and Immobilization Plant Federal Project Office. Pacific Northwest National Laboratory is operated by Battelle Memorial Institute for the U.S. Department of Energy under contract DE-AC05-76RL01830.

\section{REFERENCES}

1. J. M. Perez, S. M. Barnes, S. Kelly, L. Petkus, and E. V. Morrey, "Vitrification Testing and Demonstration for the Hanford Waste Treatment and Immobilization Plant," 
Ceram. Trans., 168 3-19 (2005).

2. J. M. Perez, Jr., D. F. Bickford, D. E. Day, D. Kim, S. L. Lambert, S. L. Marra, D. K. Peeler, D. M. Strachan, M. B. Triplett, J. D. Vienna, and R. S. Wittman, "High-Level Waste Melter Study Report," PNNL-13582, Pacific Northwest National Laboratory, Richland, WA, 2001. DOI: $10.2172 / 965722$

3. W. R. Wilmarth, G. J. Lumetta, M. E. Johnson, M. R. Poirier, M. C. Thompson, P. C. Suggs, and N. P. Machara, "Review: Waste-pretreatment Technologies for Remediation of Legacy Defense Nuclear Wastes," lvent Extr. Ion Exch., 29 [1] 1-48 (2011).

4. P. J. Certa, "River Protection Project System Plan - Revision 4," ORP-11242, Washington River Protection Solutions LLC, Richland, WA, 2009. DOI: 10.2172/973951

5. T. W. Crawford, P. J. Certa, and M. N. Wells, "System Planning with the Hanford Tank Waste Operations Simulator," WRPS-44335-FP, Washington River Protection Solutions LLC, Richland, WA, 2010. (http://www.osti.gov/ scitech/servlets/purl/970544)

6. WTP Contract, Contract DE-AC27-01RV14136, as amended, "Section C Statement of Work," U. S. Department of Energy, Office of River Protection, Richland, WA. (http:// www.hanford.gov/page.cfm/DOE-ORPPrimeContracts/ BNIContract)

7. D. Kim, P. Hrma, D. A. Larmar, and M. L Elliott, "Development of High-Waste Loaded High-Level Nuclear Waste Glasses for High-Temperature Melter," Ceram. Trans., 45 39-48 (1994).

8. J. C. Marra, K. M. Fox, D. K. Peeler, T. B. Edwards, A. L. Youchak, J. H. Gillam, Jr., J. D. Vienna, S. V. Stefanovsky, and A. S. Aloy, "Glass Formulation Development in Support of Melter Testing to Demonstrate Enhanced High Level Waste Throughput," Mater. Res. Soc. Symp. Proc., 1107 231-38 (2008).

9. D. Kim, M. J. Schweiger, J. D. Vienna, F. C. Johnson, J. C. Marra, D. K. Peeler, and G. L. Smith, "Glass Formulation for Next Generation Cold Crucible Induction Melter," WM'11 proceedings, paper No. 11561. (http://www.wmsym. org/archives/2011/papers/11561.pdf)

10. G. L. Smith, D. Kim, M. J. Schweiger, J. C. Marra, J. B. Lang, J. V. Crum, C. L. Crawford, and J. D. Vienna, "Silicate Based Glass Formulations for Immobilization of U.S. Defense Wastes Using Cold Crucible Induction Melters," PNNL-23288 (EMSP-RPT-021), Pacific Northwest National Laboratory, Richland, WA, 2014. (http://www.pnnl.gov/ main/publications/external/technical_reports/PNNL23288.pdf)

11. K. S. Matlack, M. Chaudhuri, H. Gan, I. S. Muller, W. K. Kot, W. Gong, and I. L. Pegg, "Glass Formulation Testing to Increase Sulfate Incorporation," ORP-51808 (VSL04R4960-1), U.S. Department of Energy, Office of River Protection, Richland, WA, 2005. DOI: 10.2172/1035193

12. K. S. Matlack, W. Gong, I. S. Muller, I. Joseph, and I. L. Pegg, "LAW Envelope C Glass Formulation Testing to Increase Waste Loading," ORP-56323 (VSL-05R5900-1), U.S. Department of Energy, Office of River Protection, Richland, WA, 2005. DOI: 10.2172/1109496

13. K. S. Matlack, H. Gan, W. Gong, I. L. Pegg, C. C. Chap- man, and I. Joseph, "High Level Waste Vitrification System Improvements, ORP-56297 (VSL-07R1010-1), U.S. Department of Energy, Office of River Protection, Richland, WA, 2007. DOI: 10.2172/1105982

14. K. S. Matlack, I. Joseph, W. Gong, I. S. Muller, and I. L. Pegg, "Enhanced LAW Glass Formulation Testing," ORP56293 (VSL-07R1130-1), U. S. Department of Energy, Office of River Protection, Richland, WA, 2007. DOI: 10.2172/1105974

15. K. S. Matlack, I. Joseph, W. Gong, I. S. Muller, and I. L. Pegg, "Glass Formulation Development and DM10 Melter Testing with ORP LAW Glasses," ORP-56296 (VSL09R1510-2), U.S. Department of Energy, Office of River Protection, Richland, WA, 2009. DOI: 10.2172/1105979

16. K. M. Fox, D. K. Peeler, and T. B. Edwards, "Frit Optimization for Sludge Batch Processing at the Defense Waste Processing Facility," Ceram. Nucl. Appl., Ceram. Eng. Sci. Proc., 30 [10] 185-92 (2010).

17. K. M. Fox, T. B. Edwards, and J. R. Zamecnik, "Frit Development for Sludge Batch 6," SRNL-STI-2010-00137, Savannah River National Laboratory, Aiken, SC, 2010. DOI: $10.2172 / 979693$

18. T. B. Edwards, K. G. Brown, and R. L. Postles, "SME Acceptability Determination for DWPF Process Control," WSRC-TR-95-00364, Rev. 4, Savannah River National Laboratory, Aiken, SC, 2002. DOI: 10.2172/805889

19. K. M. Fox and T. B. Edwards, "The Sludge Batch 7a Glass Variability Study with Frit 418 and Frit 702," SRNL-STI2011-00063, Savannah River National Laboratory, Aiken, SC, 2011. DOI: 10.2172/1010511

20. P. Hrma, "Melting of Foaming Batches: Nuclear Waste Glass," Glastechnische Berichte, 63K 360-69 (1990).

21. D. F. Bickford, P. Hrma, and B. W. Bowen, II, "Control of Radioactive Waste Glass Melters: II, Residence Time and Melt Rate Limitations," J. Am. Ceram. Soc., 73 [10] 290315 (1990).

22. D. Kim and P. Hrma, "Laboratory Studies for Estimation of Melting Rate in Nuclear Waste Glass Melters," Ceram. Trans., 45 409-19 (1994).

23. P. A. Smith, J. D. Vienna, and P. Hrma, "The Effects of Melting Reactions on Laboratory-scale Waste Vitrification," J. Mater. Res., 10 [8] 2137-49 (1995).

24. J. Matyas, P. Hrma, and D. Kim, "Melt Rate Improvement for High-Level Waste Glass," PNNL-14003, Pacific Northwest National Laboratory, Richland, WA, 2002. DOI: $10.2172 / 860127$

25. P. Hrma, J. Matyas, and D. Kim, "The Chemistry and Physics of Melter Cold Cap," In: $9^{\text {th }}$ Biennial Int. Conf. on Nuclear and Hazardous Waste Management, Spectrum '02, American Nuclear Society, 2002.

26. C. Chapman, "Investigation of Glass Bubbling and Increased Production Rate," REP-RPP-069, Rev. 0, Duratek, Richland, WA, 2004.

27. J. Matyas, P. Hrma, and D. Kim, "Analysis of Feed Melting Processes," Ceram. Trans., 155 69-78 (2004).

28. J. M. Perez, C. C. Chapman, R. K. Mohr, K. S. Matlack, and I. L. Pegg, "Development and Demonstration of an Air Bubbler Design to Meet High-Level Waste Melter Production Rate Requirements of the Hanford Waste Treat- 
ment and Immobilization Plant" Proceedings of the $10^{\text {th }}$ International Conference on Environmental Remediation and Radioactive Waste Management, ICEM'05, pp. 132431, 2005.

29. I. Joseph, B. W. Bowan II, H. Gan, W. K. Kot, K. S. Matlack, I. L. Pegg, and A. A. K.ruger, "High Aluminum HLW Glasses for Hanford's WTP,"WM'10 proceedings, paper No. 10241, 2010. (http://www.wmsym.org/archives/2010/pdfs/ 10241.pdf)

30. K. M. Fox, D. K. Peeler, J. C. Marra, A. Aloy, R. Soshnikov, A. Trofimenko, J. D. Vienna, B. J. Riley, D. Kim, and J. V. Crum, "International Studies of Enhanced Waste Loading and Improved Melt Rate for High Alumina Concentration Nuclear Waste Glasses," Ceram. Trans., 207 81-92 (2009).

31. D. Kim, M. J. Schweiger, W. C. Buchmiller, and J. Matyas, "Laboratory-Scale Melter for Determination of Melting Rate of Waste Glass Feeds," PNNL-21005 (EMSP-RPT-012), Pacific Northwest National Laboratory, Richland, WA, 2012. DOI: 10.2172/1036924

32. P. Hrma, M. J. Schweiger, C. J. Humrickhouse, J. A. Moody, R. M. Tate, T. T. Rainsdon, N. E. TeGrotenhuis, B. M. Arrigoni, J. Marcial, C. P. Rodriguez, and B. H. Tincher, "Effect of Glass-Batch Makeup on the Melting Process," Ceram.-Silik., 54 [3] 193-211 (2010).

33. M. J. Schweiger, P. Hrma, C. J. Humrickhouse, J. Marcial, B. J. Riley, and N. E. TeGrotenhuis, "Cluster Formation of Silica Particles in Glass Batches During Melting," J. Non-Cryst. Solids, 356 [25-27] 1359-67 (2010).

34. S. H. Henager, P. Hrma, K. J. Swearingen, M. J. Schweiger, J. Marcial, and N. E. TeGrotenhuis, "Conversion of Batch to Molten Glass, I: Volume Expansion," J. NonCryst. Solids, 357 [3] 829-35 (2011).

35. P. Hrma, J. Marcial, K. J. Swearingen, S. H. Henager, M. J. Schweiger, and N. E. TeGrotenhuis "Conversion of Batch to Molten Glass, II: Dissolution of Quartz Particles," J. Non-Cryst. Solids, 357 [3] 820-28 (2011).

36. P. Hrma and J. Marcial, "Dissolution Retardation of Solid Silica During Glass-batch Melting," J. Non-Cryst. Solids, 357 [15] 2954-59 (2011).

37. P. Hrma, A. A. Kruger, and R. Pokorny, "Nuclear Waste Vitrification Efficiency: Cold Cap Reactions," J. NonCryst. Solids, 358 [24] 3559-62 (2012).

38. D. A. Pierce, P. Hrma, J. Marcial, B. J. Riley, and M. J. Schweiger, "Effect of Alumina Source on the Rate of Melting Demonstrated with Nuclear Waste Glass Batch," Int. J. Appl. Glass Sci., 3 [1] 59-68 (2012).

39. J. Chun, D. A. Pierce, R. Pokorny, and P. Hrma, "Cold-cap Reactions in Vitrification of Nuclear Waste Glass: Experiments and Modeling," Thermochim. Acta, 559 32-39 (2013).

40. J. Marcial, J. Chun, P. Hrma, and M. J. Schweiger, "Effect of Bubbles and Silica Dissolution on Melter Feed Rheology During Conversion to Glass," Environ. Sci. Technol., 48 [20] 12173-80 (2014).

41. C. P. Rodriguez, J. Chun, M. J. Schweiger, A. A. Kruger, and P. Hrma, "Application of Evolved Gas Analysis to Cold-cap Reactions of Melter Feeds for Nuclear Waste Vitrification," Thermochim. Acta, 592 86-92 (2014).
42. R. Pokorny and P. Hrma, "Mathematical Modeling of Cold Cap," J. Nucl. Mater., 429 [1-3] 245-56 (2012).

43. R. Pokorny, D. A. Pierce, and P. Hrma, "Melting of Glass Batch: Model for Multiple Overlapping Gas-evolving Reactions," Thermochim. Acta, 541 8-14 (2012).

44. R. Pokorny, J. A. Rice, J. V. Crum, M. J. Schweiger, and P. Hrma, "Kinetic Model for Quartz and Spinel Dissolution During Melting of High-level-waste Glass Batch," J. Nucl. Mater., 443 [1-3] 230-35 (2013).

45. R. Pokorny, J. A. Rice, M. J. Schweiger, and P. Hrma, "Determination of Temperature-Dependent Heat Conductivity and Thermal Diffusivity of Waste Glass Melter Feed," J. Am. Ceram. Soc., 96 [6] 1891-98 (2013).

46. R. Pokorny and P. Hrma, "Model for the Conversion of Nuclear Waste Melter Feed to Glass," J. Nucl. Mater., 445 [1-3] 190-99 (2014).

47. C. M. Jantzen and M. J. Plodinec, "Thermodynamic Model of Natural, Medieval and Nuclear Waste Glass Durability," J. Non-Cryst. Solids, 67 [1-3] 207-23 (1984).

48. E. Saad, N. L. Laberge, and X. Feng, "Modeling of the Viscosity of Glasses Used in the Immobilization of High-Level Liquid Nuclear Waste," Nucl. Technol., 86 [1] 66-69 (1989).

49. C. M. Jantzen, "First-Principle Process Product Models for Vitrification of Nuclear Waste: Relationship of Glass Composition to Glass Viscosity, Resistivity, Liquidus Temperature, and Durability," Ceram. Trans., 23 37-51 (1991).

50. X. Feng and R. B. Metzger, "Glass Durability Model Based on Understanding Glass Chemistry and Structural Configurations of the Glass Constituents," Mater. Res. Soc. Symp. Proc., 432 27-38 (1997).

51. J. B. Pickett and C. M. Jantzen, "TCLP Leaching Prediction from the "Thermo (TM)" Model for Borosilicate Glasses," Ceram. Trans., 132 323-33 (2002).

52. A. Grandjean, M. Malki, C. Simonnet, D. Manara, and B. Penelon, "Correlation between Electrical Conductivity, Viscosity, and Structure in Borosilicate Glass-forming Melts," Phys. Rev. B, 75054112 (2007).

53. C. M. Jantzen and K. G. Brown, "Predicting the SpinelNepheline Liquidus for Application to Nuclear Waste Glass Processing. Part II: Quasicrystalline Freezing Point Depression Model," J. Am. Ceram. Soc., 90 [6] 1880-91 (2007).

54. P. Hrma, G. F. Piepel, M. J. Schweiger, D. E. Smith, D. Kim, P. E. Redgate, J. D. Vienna, C. A. Lopresti, D. B. Simpson, D. K. Peeler, and M. H. Langowski, "Property/ Composition Relationships for Hanford High-Level Waste Glasses Melting at $1150^{\circ} \mathrm{C}, "$ PNL-10359, Pacific Northwest Laboratory, Richland, WA, 1994. DOI: 10.2172/ $10121755 ; 10.2172 / 10121752$

55. D. Kim and P. Hrma, "Models for Liquidus Temperature of Nuclear Waste Glasses," Ceram. Trans., 45 327-37 (1994).

56. P. Hrma, G. F. Piepel, P. E. Redgate, D. E. Smith, M. J. Schweiger, J. D. Vienna, and D. Kim, "Prediction of Processing Properties for Nuclear Waste Glasses," Ceram. Trans., 61 505-13 (1995).

57. J. D. Vienna, P. Hrma, M. J. Schweiger, and M. H. Langowski, "Compositional Dependence of Elemental Release from HLW Glasses by the Product Consistency Test: A 
One Component-at-a-Time Study," Ceram. Trans., 72 307-16 (1996).

58. J. D. Vienna, P. Hrma, D. Kim, M. J. Schweiger, and D. E. Smith, "Compositional Dependence of Viscosity, Electrical Conductivity, and Liquidus Temperature of Multicomponent Borosilicate Waste Glasses," Ceram. Trans., 72 427-36 (1996).

59. J. D. Vienna, P. Hrma, M. J. Schweiger, M. H. Langowski, P. E. Redgate, D. Kim, G. F. Peipel, D. E. Smith, C. Y. Chang, D. E. Rinehart, S. E. Palmer, and H. Li, "Effect of Composition and Temperature on the Properties of HighLevel Waste (HLW) Glass Melting above $1200^{\circ} \mathrm{C}$," PNNL10987, Pacific Northwest National Laboratory, Richland, WA, 1996. DOI: $10.2172 / 212394$

60. G. F. Piepel, T. Redgate, and P. Masuga, "Comparison of Mixture Models and Free Energy of Hydration Models for Waste Glass Releases," Glass Technol., 38 [6] 210-15 (1997).

61. J. D. Vienna, P. Hrma, J. V. Crum, and M. Mika, "Liquidus Temperature-composition Model for Multi-component Glasses in the $\mathrm{Fe}, \mathrm{Cr}, \mathrm{Ni}$, and $\mathrm{Mn}$ Spinel Primary Phase Field," J. Non-Cryst. Solids, 292 [1-3] 1-24 (2001).

62. J. D. Vienna, D. Kim, and P. Hrma, "Database and Interim Glass Property Models for Hanford HLW and LAW Glasses," PNNL-14060, Pacific Northwest National Laboratory, Richland, WA, 2002. DOI: 10.2172/15003540

63. J. D. Vienna, D. Kim, and P. Hrma, "Interim Models Developed To Predict Key Hanford Waste Glass Properties Using Composition," Ceram. Trans., 143 151-57 (2003).

64. D. Kim and J. D. Vienna, "Glass Composition -TCLP Response Model for Waste Glasses," Ceram. Trans., 155 297-305 (2004).

65. J. D. Vienna, T. B. Edwards, J. V. Crum, D. Kim, and D. K. Peeler, "Liquidus Temperature and One Percent Crystal Content Models for Initial Hanford HLW Glasses," Ceram. Trans., 168 133-40 (2005).

66. G. F. Piepel, S. K. Cooley, I. S. Muller, H. Gan, I. Joseph, and I. L. Pegg, "ILAW PCT, VHT, Viscosity, and Electrical Conductivity Model Development," VSL-07R1230-1, Rev. 0, Vitreous State Laboratory, The Catholic University of America, Washington, D.C., 2007. DOI: 10.2172/ 1110826

67. G. F. Piepel, S. K. Cooley, A. Heredia-Langner, S. M. Landmesser, W. K. Kot, H. Gan, and I. L. Pegg, "IHLW PCT, Spinel $\mathrm{T}_{1 \%}$, Electrical Conductivity, and Viscosity Model Development," VSL-07R1240-4, Rev. 0, Vitreous State Laboratory, The Catholic University of America, Washington, D.C., 2008. DOI: 10.2172/1105987

68. G. F. Piepel, A. Heredia-Langner, and S. K. Cooley, "Property-Composition-Temperature Modeling of Waste Glass Melt Data Subject to a Randomization Restriction," J. Am. Ceram. Soc., 91 [10] 3222-28 (2008).

69. J. D. Vienna, A. Fluegel, D-S. Kim, and P. Hrma, "Glass Property Data and Models for Estimating High-Level Waste Glass Volume," PNNL-18501, Pacific Northwest National Laboratory, Richland, WA, 2009. DOI: 10.2172/ 971447

70. J. D. Vienna, D-S. Kim, D. C. Skorski, and J. Matyas,
"Glass Property Models and Constraints for Estimating the Glass to Be Produced at Hanford by Implementing Current Advanced Glass Formulation Efforts," PNNL22631, Pacific Northwest National Laboratory, Richland, WA, 2013.

71. D. Kim, P. Hrma, S. E. Palmer, D. E. Smith, and M. J. Schweiger, "Effect of $\mathrm{B}_{2} \mathrm{O}_{3}, \mathrm{CaO}$, and $\mathrm{Al}_{2} \mathrm{O}_{3}$ on the Chemical Durability of Silicate Glasses for Hanford Low-Level Waste Immobilization," Ceram. Trans., 61 531-38 (1995).

72. M. I. Ojovan, "Viscosity and Glass Transition in Amorphous Oxides," Adv. Condens. Matter Phys., Article ID 817829 (2008). DOI: $10.1155 / 2008 / 817829$

73. P. Hrma, "High-temperature Viscosity of Commercial Glasses," Ceram.-Silik., 50 [2] 57-66 (2006).

74. P. Hrma, "Arrhenius Model for High-temperature Glassviscosity with a Constant Pre-exponential Factor," $J$. Non-Cryst. Solids, 354 [18] 1962-68 (2008).

75. P. Hrma, "Glass Viscosity as a Function of Temperature and Composition: A Model Based on Adam-Gibbs Equation," J. Non-Cryst. Solids, 354 [29] 3389-99 (2008).

76. P. H. Hrma, B. M. Arrigoni, and M. J. Schweiger, "Viscosity of Many Component Glasses," J. Non-Cryst. Solids, 355 [14-15] 891-902 (2009).

77. P. H. Hrma and S. Han, "Effect of Glass Composition on Activation Energy of Viscosity in Glass-melting-temperature Range," J. Non-Cryst. Solids, 358 [15] 1118-29 (2012).

78. A. Fluegel, A. K. Varshneya, D. A. Earl, T. P. Seward, and D. Oksoy, "Improved Composition-Property Relations in Silicate Glasses, Part I: Viscosity," Ceram. Trans., 170 129-43 (2005)

79. A. Fluegel, "Glass Viscosity Calculation Based on a Global Statistical Modeling Approach," Glass Technol.: Eur. J. Glass Sci. Technol. A, 48 [1] 13-30 (2007).

80. L. A. Chick and G.F. Piepel, "Statistically Designed Optimization of Glass Composition," J. Am. Ceram. Soc., 67 [11] 763-68 (1984).

81. G. F. Piepel, C. M. Anderson, and P. E. Redgate, "Response Surface Designs for Irregularly-Shaped Regions (Parts 1, 2, and 3)," Proceedings of the Section on Physical and Engineering Sciences 1993, pp. 205-27, American Statistical Association, Alexandria, VA, 1993.

82. G. F. Piepel and J. A. Cornell, "Mixture Experiment Approaches - Examples, Discussion, and Recommendations, J. Qual. Technol., 26 [3] 177-96 (1994).

83. G. F. Piepel and T. Redgate, "Mixture Experiment Techniques for Reducing the Number of Components Applied for Modeling Waste Glass Sodium Release," J. Am. Ceram. Soc., 80 [12] 3038-44 (1997).

84. J. A. Cornell, Experiments with Mixtures: Designs, Models, and the Analysis of Mixture Data, Third Ed., John Wiley and Sons, New York, NY, 2002.

85. S. K. Cooley, G. F. Piepel, H. Gan, W. Kot, and I. L. Pegg "A Two-Stage Layered Mixture Experiment Design for a Nuclear Waste Glass Application - Part 1 and Part 2," In 2003 ASA Proceedings. Papers presented at the Annual Meeting of the American Statistical Association. Joint Statistical Meetings, San Francisco, California, August 37, pp. 1036-43 (Part 1) and 1044-51 (Part 2), American 
Statistical Association, Alexandria, VA, 2003.

86. D. Kim and J. D. Vienna, "Preliminary ILAW Formulation Algorithm Description," 24590-LAW-RPT-RT-040003, Rev. 1, River Protection Project, Hanford Tank Waste Treatment and Immobilization Plant, Richland, WA, 2012.

87. J. D. Vienna and D. Kim, "Preliminary IHLW Formulation Algorithm Description," 24590-HLW-RPT-RT-05001, Rev 1, River Protection Project, Hanford Tank Waste Treatment and Immobilization Plant, Richland, WA, 2014.

88. ASTM-American Society of Testing and Materials, "Standard Test Methods for Determining Chemical Durability of Nuclear, Hazardous, and Mixed Waste Glasses and Multiphase Glass Ceramics: The Product Consistency Test (PCT)," ASTM C 1285-14, American Society of Testing and Materials, 2014.

89. EPA-U. S. Environmental Protection Agency, "Test Methods for Evaluation of Solid Waste Physical/Chemical Methods," SW-846, 3rd. ed., as amended, U. S. Environmental Protection Agency, Washington, D. C, 1997.

90. ASTM-American Society of Testing and Materials, "Standard Test Methods for Measuring Waste Glass or Glass Ceramic Durability by Vapor Hydration Test," ASTM C 1663-09, American Society of Testing and Materials, 2009.

91. D. K. Peeler, T. H. Lorier, and J. D. Vienna, "Melt Rate Improvement for DWPF MB3: Foaming Theory and Mitigation Techniques," WSRC-RP-2001-00351, Westinghouse Savannah River Company, Aiken, Savannah River Technology Center, SC, 2001. DOI: $10.2172 / 783820$

92. D. Kim, P. Hrma, D. E. Smith, and M. J. Schweiger, "Crystallization in Simulated Glasses from Hanford HighLevel Nuclear Waste Composition Range," Ceram. Trans., 39 179-89 (1993).

93. P. Izak, P. Hrma, B. W. Arey, and T. J. Plaisted, "Effect of Feed Melting, Temperature History, and Minor Component Addition on Spinel Crystallization in High-level Waste Glass," J. Non-Cryst. Solids, 289 [1-3] 17-29 (2001).

94. J. Alton, T. J. Plaisted, and P. Hrma, "Dissolution and Growth of Spinel Crystals in a Borosilicate Glass," J. NonCryst. Solids, 311 [1] 24-35 (2002).

95. P. Hrma, J. Matyas, and D. Kim, "Evaluation of Crystallinity Constraint for HLW Glass Processing," Ceram. Trans., 143 133-40 (2003).

96. P. Hrma, "Crystallization During Processing of Nuclear Waste Glass,” J. Non-Cryst. Solids, 356 [52-54] 3019-25 (2010).

97. J. Matyas, J. D. Vienna, D. Peeler, K. Fox, C. Herman, and A. A. Kruger, "Road Map for Development of CrystalTolerant High Level Waste Glasses," PNNL-23363, Pacific Northwest National Laboratory, Richland, WA, 2014. DOI: $10.2172 / 1149233$

98. D. Kim, D. K. Peeler, and P. Hrma, "Effect of Crystallization on the Chemical Durability of Simulated Nuclear Waste Glasses," Ceram. Trans., 61 177-85 (1995).

99. H. Li, J. D. Vienna, P. Hrma, D. E. Smith, and M. J. Schweiger, "Nepheline Precipitation in High-Level Waste Glasses: Compositional Effects and Impact on the Waste
Form Acceptability," Mater. Res. Soc. Symp. Proc., 465 261-68 (1997).

100. D. F. Bickford and C. M. Jantzen, "Devitrification of SRL Defense Waste Glass," Mater. Res. Soc. Symp. Proc., 26 557-65 (1984)

101. H. Li, P. Hrma, J. D. Vienna, M. Quin, Y. Su, and D. E. Smith, "Effects of $\mathrm{Al}_{2} \mathrm{O}_{3}, \mathrm{~B}_{2} \mathrm{O}_{3}, \mathrm{Na}_{2} \mathrm{O}$, and $\mathrm{SiO}_{2}$ on Nepheline Formation in Borosilicate Glasses: Chemical and Physical Correlations," J. Non-Cryst. Solids, 331 [1-3] 202-16 (2003).

102. J. S. McCloy and J. D. Vienna, "Glass Composition Constraint Recommendations for Use in Life-Cycle Mission Modeling," PNNL-19372, Pacific Northwest National Laboratory, Richland, WA, 2010. DOI: 10.2172/978973

103. J. S. McCloy, M. J. Schweiger, C. P. Rodriguez, and J. D. Vienna, "Nepheline Crystallization in Nuclear Waste Glasses: Progress Toward Acceptance of High-Alumina Formulations," Int. J. Appl. Glass Sci., 2 [3] 201-14 (2011)

104. J. D. Darab D. D. Graham, B. D. MacIsaac, R. L. Russell, D. K. Peeler, H. D. Smith, and J. D Vienna, "Sulfur Partitioning During Vitrification of INEEL Sodium Bearing Waste: Status Report," PNNL-13588, Pacific Northwest National Laboratory, Richland, WA, 2001. DOI: 10.2172/ 965662

105. P. Hrma, J. D. Vienna, and J. S. Ricklefs, Mechanism of Sulfate Segregation During Glass Melting; Vol. 757, pp. 147-52, Materials Research Society Symposium Proceedings, 2003.

106. P. Hrma, J. D. Vienna, W. C. Buchmiller, and J. S. Ricklefs, "Sulfate Retention during Waste Glass Melting," Ceram. Trans., 155 93-99 (2004).

107. P. Hrma, J. D. Vienna, B. K. Wilson, T. J. Plaisted, and S. M. Heald, "Chromium Phase Behavior in a Multi-component Borosilicate Glass Melt," J. Non-Cryst. Solids, 352 [21-22] 2114-22 (2006)

108. J. D. Vienna, D. Kim, I. S. Muller, G. F. Piepel, and A. A. Kruger, "Toward Understanding the Effect of Nuclear Waste Glass Composition on Sulfur Solubility," J. Am. Ceram. Soc., 98 [10] 3135-42 (2014).

109. L. R. Bunnell, "Laboratory Work in Support of West Valley Glass Development," PNL-6539, Pacific Northwest Laboratory, Richland, WA, 1988. DOI: 10.2172/5196678

110. D. Kim, M. J. Schweiger, C. P. Rodriguez, W. C. Lepry, J. B. Lang, J. V. Crum, J. D. Vienna, F. C. Johnson, J. C. Marra, and D. K. Peeler, "Formulation and Characterization of Waste Glasses with Varying Processing Temperature," PNNL-20774 (EMSP-RPT-009), Pacific Northwest National Laboratory, Richland, WA, 2011. DOI: 10.2172/ 1028572

111. D. Kim and J. D. Vienna, "Influence of Glass Property Restrictions on Hanford HLW Glass Volume," Ceram. Trans., 132 105-15 (2002)

112. P. J. Certa, T. M. Hohl, A. M. Johnson, S. L. Orcutt, R. S. Wittman, and D. Kim, "Sensitivity of Hanford Immobilized High-Level Waste Glass Mass To Chromium and Aluminum Partitioning Assumptions," RPP-20003, Rev. 1, CH2M Hill Hanford Group, Inc., Richland, Washington, 2005. DOI: 10.2172/837967 